\title{
河床表面分形度量及其在河型判别中的 应用
}

陈文䂞 ${ }^{(1)}$ ，魏加华 (2) (3*，李美姣 ${ }^{(1)}$ ，周银军 ${ }^{(4)}$

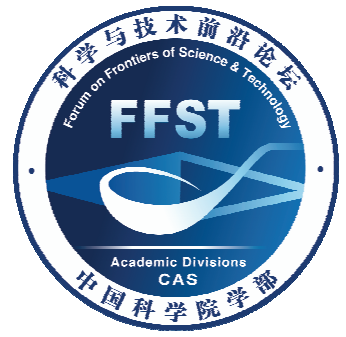

(1) 中南财经政法大学金融学院, 武汉 430073;

(2) 清华大学水沙科学与水利水电工程国家重点实验室, 北京 100084;

(3) 青海大学水利电力学院, 西宁 810016 ;

(4) 长江科学院河流研究所, 武汉 430010

*E-mail: weijiahua@mail.tsinghua.edu.cn

收稿日期: 2015-04-10; 接受日期: 2015-06-10

国家自然科学基金(批准号: 51309138, 51109011, 71473274)资助项目

\begin{abstract}
摘要 将表面分维概念引入河流动力学, 提出河床表面形态的分形度量方法, 并通过实 际河段分析与概化模型试验结合的手段，对不同河型亚类、不同基本河型的河床表面分形 维数进行对比研究, 并将河床表面分形维数应用于河型判别. 结果表明: 由于河床形态是 河型判别的一个主要依据, 而河床表面分形维数又可对河床形态进行整体度量, 因此河床 表面分形维数可在一定程度上体现河型、甚至河型亚类之间的差异, 实际分汉河段比较中, 微弯高水分汉的河床表面分形维数最大、弯曲低水分汉及顺直中水分汉次之、微弯低水分 汊最小; 在试验范围内, 一定流量下, 则是分汉河型的河床表面分形维数最大、弯曲河型次 之、顺直河型最小, 可以认为在收集更多实测河段资料并统一算法后, 河床表面分形维数 可作为河型的判据之一.
\end{abstract}

\section{1 引言}

河型判别是河流动力学中的一个基础问题, 并 涉及地质、地理及水利等多个学科, 因不同学科的出 发点和理论依据有所不同, 因此, 河型问题研究十分 复杂，且标准不一 ${ }^{[1]}$. 当前河型的判别依据有很多, 如河床、河岸的可动性 ${ }^{[2,3]}$, 河流的能耗性 ${ }^{[4,5]}$, 输沙特 性 ${ }^{[6] 8]}$ 以及河床形态 ${ }^{[9,10]}$ 等. 总之, 无论哪种判据, 河 床形态都是其中必不可少的一个组成 ${ }^{[11,12]}$. 如: 包含 纵向形态指标的判别依据“河谷比降-输沙率、曲率”

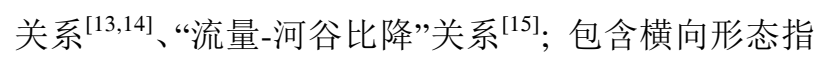

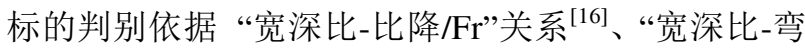
曲系数”关系 ${ }^{[17]}$, “宽深比-无量纲切力”关系 ${ }^{[18]}$; 包含 平面形态指标的判别依据弯曲系数 ${ }^{[19]}$ 、分汉程度 ${ }^{[20] 、}$ 游荡程度 ${ }^{[21]}$ 、河漫滩相对(河宽) 宽度 ${ }^{[22]}$, “曲率-粘土 含量百分数”关系 ${ }^{[23]}$ 等.

显然，受研究手段的限制，传统上应用河床形态 于河型判别时多采用的是二维剖面 ${ }^{[24]}$, 如平面形态、 纵剖面形态以及断面形态等, 但实际中床面形态是 三维性的 ${ }^{[25,26]}$, 且可以由近年兴起的非线性-分形理

引用格式: 陈文否, 魏加华, 李美姣, 等. 河床表面分形度量及其在河型判别中的应用. 中国科学: 技术科学, 2015, 45: 1073-1079 Chen W L, Wei J H, Li M J, et al. Fractal measurement of river bed surface and its application on river pattern discrimination (in Chinese). Sci Sin Tech, 2015, 45: 1073-1079, doi: 10.1360/N092015-00061 
论来进行度量 ${ }^{[27]}$. 目前已有研究者将分形理论应用 于量化河床形态的各二维剖面, Sapozhnikov ${ }^{[28]}$, $\operatorname{Kevin}^{[29]}$, David ${ }^{[30]}$ 等先后研究了河段平面形态(河长) 的分形特征, 认为河床形态分维 $D$ 体现了河流的蜿 蜒程度, 甚至可用于河型判别; Ashmore ${ }^{[3]}$ 对河道断 面及深泓纵剖面分维进行了研究, 认为河道纵剖面 分维体现了河道纵剖面的曲折性, 可作为河流纵向 消能的一种量度. 总体而言, 目前对河流形态分形度 量的研究多是针对某个剖面的线分维(其分维数介于 1 2) 度量, 而对于整个河床表面形态的分形度量(属 于面分维, 介于 2 3)则是比较少的.

本文首先将面分维概念引入河流动力学, 然后 通过实际河段分析与概化模型试验结合的手段, 对 不同河型亚类、不同基本河型的河床表面分形维数 (Bed Surface fractal Dimension, 以下简称 BSD, 介于 $2 \sim 3)$ 进行对比研究, 尝试将 BSD 应用于河型判别.

\section{BSD 计算方法}

BSD 计算在分形理论中属于表面分维的范畴. 作为一个新兴的理论, 面分维的计算方法有很多, 目 前还没有形成相应的规范可供遵循, 我们在此提出 一种 BSD 的面分维计算方法:

(1) 数据源来自实测河道水下地形图(DWG 格式) 或试验测量所得文本, 在提取高程数据以后利用 GIS 软件建立床面 DEM, 以此作为分维分析的对象;

(2) 采用投影覆盖法(表面积-尺码法 ${ }^{[17]}$ 的一种) 来对河道 DEM 进行分形分析, 计算出河床表面 的 分形维数, 图 1 为投影覆盖法示意图, 式(1)为计算

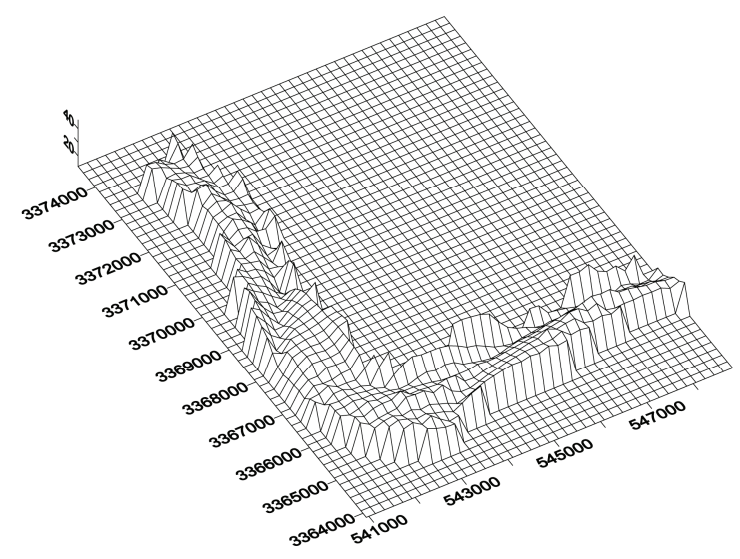

图 1 河床表面投影覆盖法示意图
公式.

$$
D=2-\frac{\ln A(r)-\ln A_{p}(r)}{\ln r},
$$

其中: $A(r)$ 是不同尺度下的河床表面积; $r$ 是不同的尺 码, 即覆盖计算对象所用方格的边长, 从小至大呈倍 数递进关系; $A_{p}(r)$ 是不同尺度下的河床平面面积, 显 然, 对于规则边界, $A_{p}(r)$ 为一常数, 可记为 $C_{0}$, 对与 河道这种具有不规则边界的表面，不同的尺码覆盖， 所得的 $A_{p}(r)$ 则是不同的; $D$ 即为河床表面的分形维数, 介于 2 3 之间. $D$ 求解与求单一曲线的方法类似, 用 不同的尺度 $r$ 求出不同的面积 $A$, 然后分别将 $A / r^{2}$ 和 $r$ 取对数, 并运用线形回归拟合直线, 得到斜率 $K$, 床 面分维值 $D$ 即为 $2-K$, 图 2 即为 BSD 计算示意图.

值得注意的是：上述计算 BSD 的方法同样存在 无标度区判定的问题, 本文采用的是人工判定法确 定无标度区. 经过所选河段的相关实验, 发现方格尺 度及无标度区判定均会对分维计算结果产生影响. 经过相关试验, 并考虑到实际河道地形的测量精度, 本文实际河段 $r$ 的取值范围设定为 $\left(52 \mathrm{~m}, 52 \times 2^{4} \mathrm{~m}\right)$, 模型河段 $r$ 的取值范围设定为 $\left(0.025 \mathrm{~m}, 0.025 \times 2^{4} \mathrm{~m}\right)$.

\section{3 典型实际河段分形维数的变化分析}

\section{1 典型河段的整体河势}

基于 2003 年 3 月至 2008 年 3 月原观分析资料, 对长江三峡枢纽下游近坝段中四个典型河段的分形 维数进行了计算和分析, 四个河段的基本河型同为 分汉河型、床沙均为沙卵石河床、长度在 12 14 km 之间，具体河段名称、位置及简要河势见图 3.

宜昌分汉段为一顺直中水分汉河段，上接镇川 门, 下至下临江坪, 全长 $14 \mathrm{~km}$, 处于山区河道与平

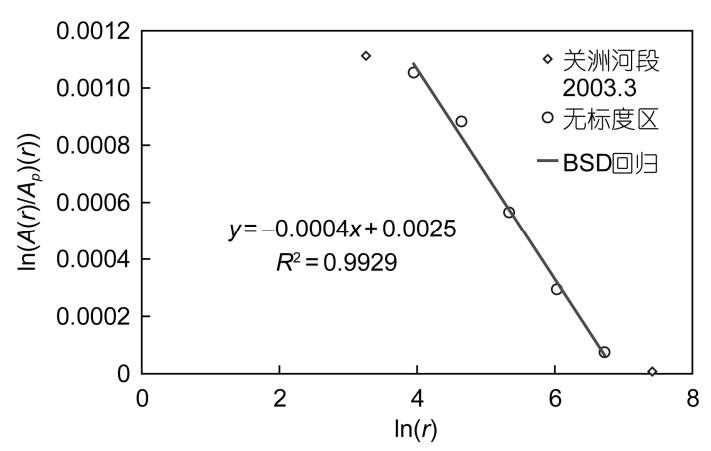

图 2 河床表面积与码尺的双对数关系示意图 


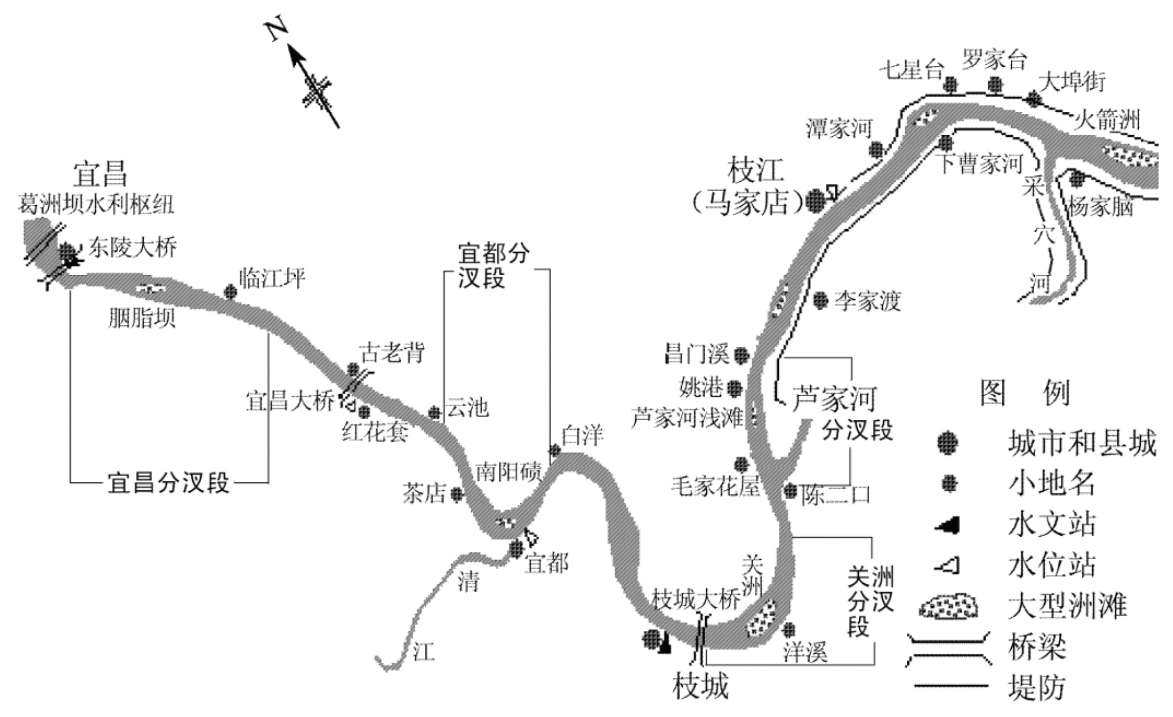

图 3 分析河段示意图

原河道之间的过渡段. 河段较大的洲滩为胭脂坝, 属 于硬土砂砾质江心洲. 宜都分汉河段距离宜昌 $39 \mathrm{~km}$, 上起云池, 下至白洋镇, 全长 $14 \mathrm{~km}$, 为急弯、低水分 汊河段. 在河段右岸弯顶略下的位置有清江入汇, 在 清江入汇口稍上的河心有南阳碛潜洲, 水道因此分 为左右两泓, 左泓为沙泓, 右泓为石泓. 河段内左岸 有中沙咀边滩和沙坝湾边滩, 右岸有三马溪边滩和 大石坝边滩. 关洲分汉段位于长江中游荆江河段进 口, 属双股微弯、高水分汉河型, 起于枝城大桥, 止 于伍家口, 长 $14 \mathrm{~km}$. 关洲左汊习称为关洲夹, 为次 槽, 右汊为主槽, 为常年主航道. 关洲为砂卵石江心 洲, 河道左岸有沙集坪边滩和同心垸边滩.

芦家河分汉段自陈二口至昌门溪, 全长 $12 \mathrm{~km}$, 为微弯低水分汉、且有分流口的水道, 其进口右侧有 松滋河分流入洞庭湖. 河道内有碛坝将河槽分为两 汊, 沙泓位于左侧, 为枯水期主航道; 石泓位于右侧, 为中、洪水期主航道.

\section{2 各河段 BSD 变化分析}

根据各河段各年枯水期实测水下地形图, 采用 上文所述的表面积一一尺度法, 计算出各河段蓄水后 BSD, 如表 1 .

由表 1 可以看出: 尽管各河段蓄水后不同年份其 BSD 随着河道冲淤调整而发生着变化, 但同一时期 不同分汊河段的 BSD 不同, 作为微弯高水分汊河 型的关洲分汉段 BSD 最大, 而弯曲低水分汉河型
的宜都分汉段及顺直中水分汉河型的宜昌分汉段 次之, 微弯低水分汉河段的芦家河分汉段最小. 可 见, BSD 在一定程度上能体现同一河型不同亚类的 差异.

\section{4 不同河型河床形态分形度量的试验研究}

\section{1 概化模型试验设计}

为研究不同河型河床分形维数的差异, 采用概 化模型水槽试验方法，对不同基本河型的河床表面 分形维数进行研究. 因此针对三种常见河型设计三 个概化模型, 通过施放同样的流量一一水位条件来塑 造适宜的河床形态. 试验共建立了三个概化水槽模 型, 涵盖顺直、弯曲、分汉三种河型, 三种河型概化 模型设计几何参数对比而言, 其进、出口河段尺寸、 试验段河长、整体坡降均是相同的, 顺直河型及弯曲 河型的试验段槽宽均为 $1 \mathrm{~m}$, 与分汉河型的中水河宽 亦基本一致, 所不同的只是试验段的平面几何形态, 以体现出河型的差异.

模型设计的参考原型为长江中下游河段. 考虑 实验场地大小等因素, 确定了模型的水平比尺为 $\lambda_{\mathrm{l}}=1000$, 垂直比尺 $\lambda_{\mathrm{h}}=50$, 其他主要比尺如表 2 所示. 共设了从洪至枯五级流量以及相应的两套出口水位 方案, 试验就河型与出口水位方案分为四个大组. 每 组试验中其河道基本几何尺寸以及水位一一流量关 系均需符合概化模型的设计要求. 
表 1 各典型河段历年河床表面分形维数统计

\begin{tabular}{cccccccc}
\hline 时间 & 2003.3 & 2004.3 & 2005.3 & 2006.3 & 2007.3 & 2008.3 & 河型亚类 \\
\hline 宜昌分汉段 & 2.000201 & 2.000215 & 2.000243 & 2.000256 & 2.000262 & 2.000274 & 顺直中水分汊 \\
宜都分汉段 & 2.000188 & 2.000217 & 2.000253 & 2.000301 & 2.000289 & 2.000303 & 弯曲低水分汊 \\
关洲分汉段 & 2.000367 & 2.000315 & 2.000371 & 2.000330 & 2.000379 & 2.000393 & 微弯高水分汊 \\
芦家河分汉段 & 2.000117 & 2.000055 & 2.000077 & 2.000072 & 2.000094 & 2.000081 & 微弯低水分汊 \\
\hline
\end{tabular}

表 2 概化模型比尺表

\begin{tabular}{cc||cc}
\hline 比尺名称 & 比尺数值 & 比尺名称 & 比尺数值 \\
\hline 平面比尺 $\lambda_{L}$ & 1000 & 沉速比尺 $\lambda \omega$ & 1.581 \\
垂直比尺 $\lambda_{h}$ & 50 & 起动比尺 $\lambda_{V_{0}}$ & 7.071 \\
流速比尺 $\lambda_{V}$ & 7.071 & 粒径比尺 $\lambda_{d_{1}}$ & $0.579 \sim 0.531$ \\
流量比尺 $\lambda_{Q}$ & 353553 & 河床变形时间比尺 $\lambda_{t_{2}}$ & 2985 \\
\hline
\end{tabular}

由于本试验主要针对长江中下游河段, 考虑三 峡蓄水后来沙量很小, 因此该模型进口不加沙, 床沙 的选择则是根据长江中游河段的床沙粒径计算所得, 选择粒径为 $0.3 \sim 0.5 \mathrm{~mm}$ 的煤粉为模型沙, 不均匀系 数为 1.3 , 可以考虑为均匀沙, 整个试验设计为清水 造床的动床试验, 河岸为固定边界. 各概化模型的初 始形态及尺寸如图 4 所示, 从上至下依次为分汉河 型、顺直河型和弯曲河型.

分汉河段模型长 $30 \mathrm{~m}$ ，整体坡降为 $0.53 \%$ ，其中 进水段(进水口 CS5)和出水段(CS25 出水口)均为长 $10 \mathrm{~m}$ 的定床段, 使水流通过长距离的消能和调整,
平稳的流入和流出分汊河道，坡降均为 $0.4 \%$ 。 CS5 CS25 之间长 $10 \mathrm{~m}$, 为分汉段, 顺直一汉坡降为 $0.8 \%$, 分汉段断面间距均为 $0.5 \mathrm{~m}$. 分汉河道上下游 单一段主槽宽 $0.8 \mathrm{~m}$, 两汉道底宽均为 $0.35 \mathrm{~m}$. 江心 洲长 $7.3 \mathrm{~m}$, 宽 $2.3 \mathrm{~m}$, 江心洲岸边与汉道河床以 $1: 3$ 的坡度相接, 江心洲高 $0.3 \mathrm{~m}$. 测量范围为 CS7 至 $\mathrm{CS} 21$, 设计为动床, 河长为 $7.7 \mathrm{~m}$ (沿弯曲一汊). 顺 直河道概化模型是在分汉河道模型的基础上改建而 成. 平面布置如图 4(c), 为保证河长的一致性, 其试 验段长度设为 $7.75 \mathrm{~m}$, 位置依然位于 $30 \mathrm{~m}$ 水槽中段, 模型概化为矩形断面，槽宽为 $1 \mathrm{~m}$, 其上下游均有一
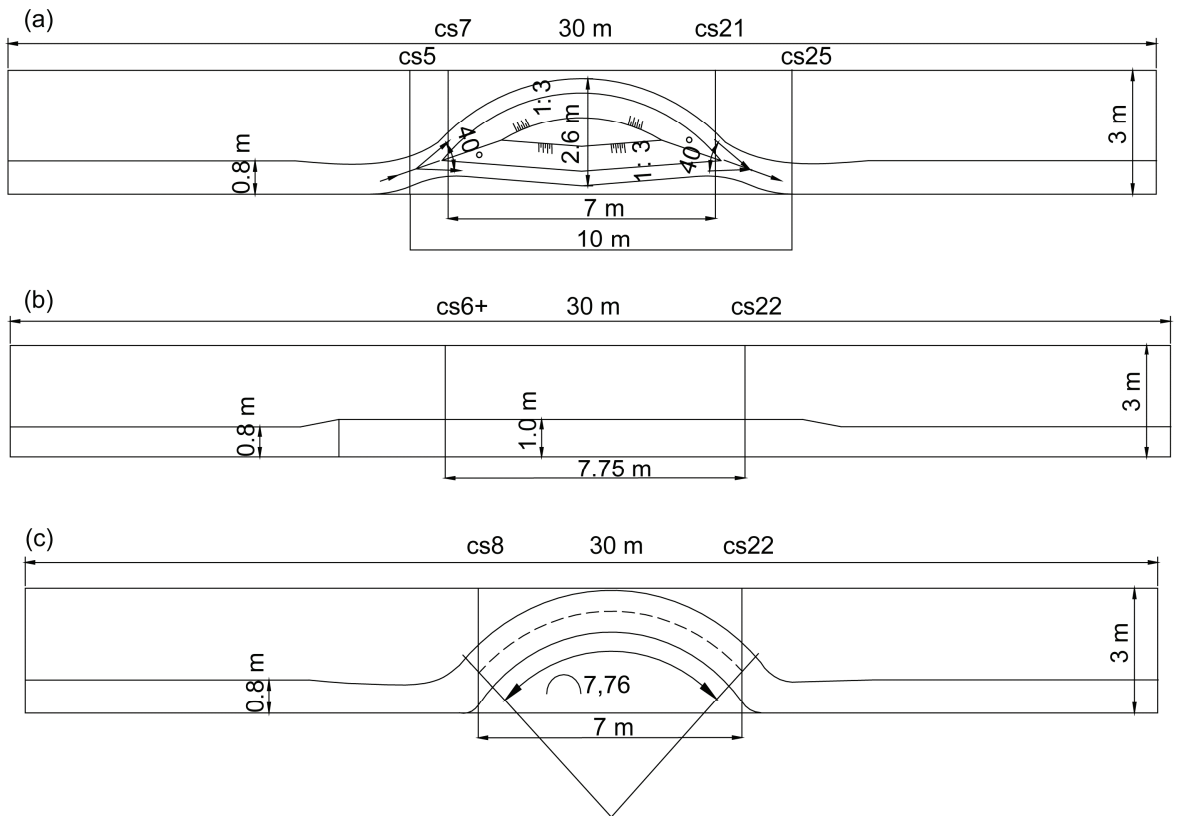

图 4 不同河型概化模型初始形态及尺寸 
宽度渐变衔接段, 以保证试验段内水流流态的平稳. 试验布置的其余部分与分汉河道模型基本相同.

弯曲河道概化模型的进、出口段、断面布置等亦 与分汉模型相同, 弯道中心线长为 $7.76 \mathrm{~m}$, 河道曲率 为 1.11 , 弯道中心角为 $91^{\circ}$, 弯曲半径为 $4.9 \mathrm{~m}$, 模型 概化为矩形断面, 槽宽仍为 $1 \mathrm{~m}$.

床面高程测量采用断面法, 断面间距为 $0.5 \mathrm{~m}$, 每个断面上测点密度为每 $5 \mathrm{~cm}$ 一个测点. 值得指出 的是, 每一组次试验, 一般都要进行 6 次地形观测(包 括初始地形), 每次间隔时间为 $3 \mathrm{~h}$, 即每次试验连续 放水历程不短于 $15 \mathrm{~h}$.

\section{2 河床表面分形维数与河型的关系}

河型划分的一个主要方法就是依据河床形态、尤 其是平面形态及其演变特性进行统计分析, 前面的 分析表明 BSD 可用来量化表达河床形态, 且能反映 不同河型的演变特性, 因此, BSD 与河型之间存在着 必然联系.

本文所进行的三个不同河型的造床试验, 其中 顺直、弯曲河型概化试验的初始床面均为平床, 其初 始河床形态显然不能完全体现出河型的差异. 因此, 选取每组试验后三个测次所得的 BSD 值, 即假设在 冲刷开始第九小时以后, 认为各组试验地形已经具 有各自河型特点, 将此后的 BSD 值与流量级点绘成 图, 如图 5.

从图中可以看出, 在本试验范围内, 不同河型的 BSD 呈明显的分区特征, 即 BSD 可以区分出不同河 型, 三个河型对比, 在一定流量情况下, 分汉河型的 BSD 最大、弯曲河型次之、顺直河型最小, 即说明就 河床形态复杂程度而言, 分汊河型、弯曲河型、顺直 河型依次减小, 这与传统认识基本一致.

需要说明的是, 图 5 由本文概化模型试验得来,

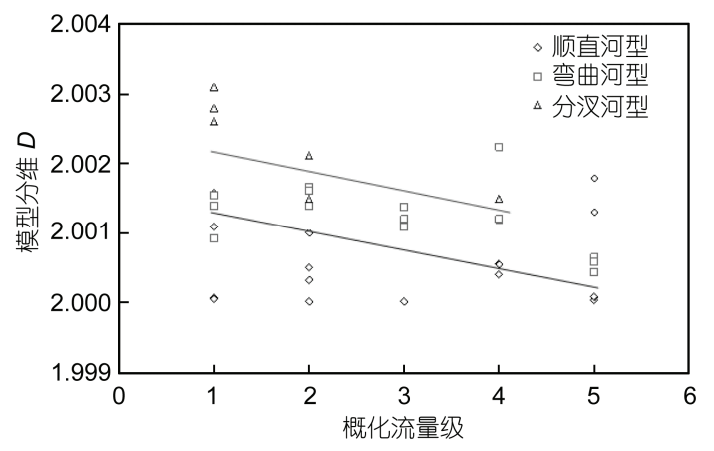

图 5 不同河型 BSD 的分区图

一方面模型为变态, 纵向尺度相对较大, 因此床面复 杂程度一般较原型为大, 因此计算出的 BSD 值一般 亦较原型大, 因此此图具有定性作用, 定量则不合适; 另一方面, BSD 存在于一定尺度范围内, 不同的无标 度区范围, 其值可能不同, 故在实际 BSD 划分河型 时, 需要统一无标度区及分形计算方法. 同时, 一个 成熟科学的河型判据需要大量的数据, 尤其是原型 河段的支持. 本文试验提供了一个方法和思路, 但还 需要收集更多的实际河段样本资料, 才能确立采用 床面形态分形维数区分河型的方法.

\section{5 结论}

河床表面分形维数可在一定程度上体现河型、甚 至河型亚类之间的差异, 实际分汉河段比较中, 是微 弯高水分汉床面分维最大、弯曲低水分汉及顺直中水 分汉次之、微弯低水分汊最小; 在本文试验范围内, 一定流量下, 分汉河型的床面分维最大、弯曲河型次 之、顺直河型最小. 可以认为: 在收集更多实测河段 资料并统一算法后, 河床表面分形维数可作为河型 的判据之一.

\section{参考文献}

1 王兴奎, 郡学军, 王光谦, 等编著. 河流动力学. 北京: 科学出版社, 2004: 189-233

2 Daniel A M, Frank W. Equal-mobility bed load transport in a small, step-pool channel in the Ouachita Mountains. Geomorphology 2003, 55: 139-154

3 Luca M, Nicola S. Observations on sediment mobility in a large gravel-bed river. Geomorphology 2010, 114: 326-337

4 Lorenzo G, Paolo P. On quantifying ecologically sustainable flow releases in a diverted river reach. Journal of Hydrology, 2013, 489: 98-107

5 Furat A M. Al-Faraj, Miklas S. Assessment of temporal hydrologic anomalies coupled with drought impact for a transboundary river flow 
regime: The Diyala watershed case study. Journal of Hydrology, 2014, 517: 64-73

6 Williams N D, Walling D E, Leeks G J L. High temporal resolution in situ measurement of the effective particle size characteristics of fluvial suspended sediment. Water Research 2007, 41: 1081-1093

7 Achim A B, Katja L. Sediment sources, spatiotemporal variability and rates of fluvial bedload transport in glacier-connected steep mountain valleys in western Norway (Erdalen and Bødalen drainage basins). Geomorphology, 2015, 228: 552-567

8 Kwan T L, Yang C C. Estimation of sediment yield during storms based on soil and watershed geomorphologycharacteristicsJournal of Hydrology, 2010, 382: 145-153

9 David J M, Andrew R G. Large Magnetic tracing of fine-sediment over pool-riffle morphology. CATENA, 2014, 115: 134-149

10 Li S S, Millar R G, Islam S. Modelling gravel transport and morphology for the Fraser River Gravel Reach, British Columbia Geomorphology, 2008, 95: 206-222

11 Lorenzo B, Alessandro V, Brett F S. A balanced treatment of secondary currents, turbulence and dispersion in a depth-integrated hydrodynamic and bed deformation model for channel bends. Advances in Water Resources, 2010, 33: 17-33

12 Judith R, Jesús G. Spatial-temporal fluvial morphology analysis in the Quelite river: It's impact on communication systemsJournal of Hydrology, 2012, 412-413: 269-278

13 Jonathan D P, Michael C S. Downstream trends in discharge, slope, and stream power in a lower coastal plain river.Journal of Hydrology, 2007, 334: 290-303

14 Alessandra M, Daniele T, James A, et al. Multi-scale streambed topographic and discharge effects on hyporheic exchange at the stream network scale in confined streams. Journal of Hydrology, 2014, 519: 1997-2011

15 Nele K M, Wolfgang S, Oliver K, et al. Estimating the topographic predictability of debris flows. Geomorphology, 2014, 207: 114-125

16 Kamal T, Francisco G, Hassan M, et al. Geologic controls on bedrock channel width in large, slowly-eroding catchments: Case study of the New River in eastern NorthAmerica. Geomorphologu, 2015, 230: 51-63

17 Sébastien C, Philippe Y. The influence of surface slope on the shape of river basins: Comparison between nature and numerical landscape simulations. Geomorphology, 2013, 192: 71-79

18 Roy N G, Sinha R. Effective discharge for suspended sediment transport of the Ganga River and its geomorphic implication. Geomorphology, 2014, 227: 18-30

19 Lu J Y, Liao X Y, Zhao G S. Experimental study on effects of geometric distortion upon suspended sediments in bendingchannels Sedimentary Geology, 2013, 294: 27-36

20 Peter M. On geometrical scaling of Cayley trees and river networks Journal of Hydrology, 2006, 322: 199-210

21 Ian C F, Andrew R G, David J M. Quantifying channel development and sediment transfer following chute cutoff in a wandering gravel-bedriver Geomorphology, 2003, 54: 307-323

22 Bastiaan N, Hervé P. Multi-scale factors controlling the pattern of floodplain width at a network scale: The case of the Rhône basin, France. Geomorphology, 2013, 200: 155-171

23 Xia J Q, Zong Q L, Deng S S, et al. Seasonal variations in composite riverbank stability in the Lower Jingjiang Reach, China Journal of Hydrology, 2014, 519: 3664-3673

24 Mourad H, Yves S, Paul B, et al. A two-dimensional finite element drying-wetting shallow water model for rivers and estuaries. Advances in Water Resources, 2000, 23: 359-372

25 Hua Z L, Li G, Chu K J. Experiments of Three-Dimensional Flow Structure in Braided Rivers Journal of Hydrodynamics, Ser. B, 2009, 21 : 228-237

26 Jia D D, Shao X J, Wang H, et al. Three-dimensional modeling of bank erosion and morphological changes in the Shishou bend of the middle Yangtze RiverAdvances in Water Resources, 2010, 33: 348-360

27 Shen X H, Zou L J, Zhang G F, et al. Fractal characteristics of the main channel of Yellow River and its relation to regional tectonic evolution Geomorphology, 2011, 127: 64-70

28 Sapozhnikov V B, Foufpula G E. Self-affinity in braided rivers [J]. Water Resour Res, 1996, 32: 1429-1439

29 Kevin H G, Thomas L T, Thomas C Y. The significance of shear stress in the agglomeration kinetics of fractal aggregates. Water Research, 1998, 32: 2660-2668

30 David A B, Mark M M, Jordan R. Fractional calculus in hydrologic modeling: A numerical perspective. Advances in Water Resources, 2013, 51: 479-497

31 Ashmore P. Morphology and Dynamics of Braided Rivers. Reference Module in Earth Systems and Environmental Sciences Treatise on Geomorphology. 2013, 289-312 


\title{
Fractal measurement of river bed surface and its application on river pattern discrimination
}

\author{
CHEN WenLei ${ }^{1,2}$, WEI JiaHua ${ }^{2,3}$, LI MeiJiao $^{1} \&$ ZHOU YinJun $^{4}$ \\ ${ }^{1}$ School of Finance, Zhongnan University of Economics and Law, Wuhan 430073, China; \\ ${ }^{2}$ Key Laboratory for River Dynamics and Hydraulic Engineering, Tsinghua University, Beijing 100084, China; \\ ${ }^{3}$ School of Water Resources and Electric Power, Qinghai University, Xining 810016, China; \\ ${ }^{4}$ Changjiang River Scientific Research Institute, Wuhan 430010, China
}

In this paper, theory of surface-fractal are introduced into the river dynamics, and the riverbed surface fractal dimension is put forward to measure river bed, based on the combination of observed data analysis and generalized model experiment, the riverbed surface fractal dimension of different base patterns and different subclass patterns are compared and researched. The riverbed surface fractal dimension is tried to be used in discrimination of river pattern. The main results are as follows: because riverbed form was a major criterion of river pattern discrimination and the riverbed surface fractal dimension can measure riverbed form in the whole, the river bed surface fractal dimension can reflect the difference among river-patterns, even subclass to some extent. The comparison of actual reaches shows that the bed surface fractal dimension of slight bending high-water braided reach is the maximum, bending low-water braided reach and straight middle-water braided reach are second, slightly bending shallow braided reach is the smallest; in generalized model experiment, the bed surface fractal dimension of braided river is the largest in all the models, bending river is the second, straight river is minimum. We can sure that bed surface fractal dimension should be a distinguished criterion of river-pattern after gather more actual information and unified fractal algorithm.

river dynamics, river pattern, riverbed surface fractal dimension, braided river, generalized model

doi: 10.1360/N092015-00061 